\title{
Extrinsic Motivators and Contextual Performance of Communication and Media Teachers in Chinese Colleges and Universities
}

\author{
Danna Hao ${ }^{1}$, Zhongwu $\mathrm{Li}^{1}$ \\ ${ }^{1}$ International College, National Institute of Development Administration, Bangkok, Thailand \\ Correspondence: Danna Hao, International College, National Institute of Development Administration, Bangkok, \\ Thailand.
}

Received: Mar. 23, 2020

Accepted: Apr. 21, $2020 \quad$ Online Published: Apr. 23, 2020

doi:10.11114/jets.v8i5.4826

URL: https://doi.org/10.11114/jets.v8i5.4826

\begin{abstract}
Communication and media teachers are a special group in Chinese colleges and universities, and it is essential to stimulate their positivity toward and enthusiasm for work. In this study, a model based on the extrinsic motivators of college communication and media teachers has been built to analyze the significant effect of the extrinsic motivators of college communication and media teachers on each element of contextual performance. It was found that salary and benefits have no significant effect on surrounding contextual performance, while organizational environment and personal development are positively related to surrounding relationships, and extrinsic motivators are positively related to organizational dedication performance.
\end{abstract}

Keywords: communication and media teachers, extrinsic motivators, contextual performance, performance evaluation

\section{Background}

In the face of the challenges brought about by the knowledge economy and fierce international competition, higher education has increased in its relevance to talent training strategies and cannot be ignored. It is the obligation of colleges and universities to cultivate senior specialized personnel and promote the development of science and technology to realize the industrialization of these two sectors. The strength of the cultural transformation proposed by U.S. cultural theorist Daniel Bell has only increased since the beginning of this century, especially the mainstream cultural form of modern society, which is the art forms of film and television. Compared with text, despite the existence of "text art," more knowledge and information is transmitted through visual/audial media. Film and television programs break through the limitations of time, space, and teach by virtue of the advantages of sound and image, and the combination of audio-visual quality, compatibility, and popularity. As powerful mass media, film and television have become increasingly important and an integral part of the ecological environment of human beings. They influence many aspects of life, such as clothing, food, shelter, behavior, and thinking. Therefore, colleges and universities pay more and more attention to the education of art students, especially those in film and television media. Due to the increasing number of students majoring in film, television and media, the demand for film and television teachers in universities has also increased. Media education can be achieved through multiple channels, including higher media education, inductive media education by media organizations, and film and television media skills training conducted by non-governmental organizations.

From the perspective of management science, performance management is an important part of management science. In general, an organization with a high level of performance and an efficient management system can reach its strategic goals more successfully and rapidly and thus complete their organizational tasks more effectively. Therefore, the organizations also attach increasing importance to performance management, leading to an increase in its research. However, compared to Western countries, performance management in China is laggardly, especially the performance management of colleges and universities, with most only focusing on the evaluation of teachers and ignoring other factors. The performance evaluation of college teachers currently lacks rationality and empirical understanding, which as a result has affected the development of college teachers to a certain extent, and has also hindered the development of colleges and universities (Wang, 2012). It is worth mentioning that research on performance incentives for media teachers in colleges and universities is closely related to the current overall development level of Chinese colleges and universities and the corresponding restrictive policies, and has maintained a corresponding steady development for a 
considerable period of time. In addition, under the constraints of strict college and university management systems, the professional characteristics and group characteristics of communication and media teachers in colleges and universities have distinctive performances. In the final analysis, teachers are the core and starting point for studying the evaluation of job performance management by colleges and universities.

\subsection{Research Questions}

Regarding the above discussion, this research is based on the growth motivators of communication and media teachers in Chinese colleges and universities, and proposes the following research questions: (1) What are the extrinsic motivators affecting communication and media teachers? (2) How to classify the contextual performance? (3) What is the relationship between the various extrinsic motivators and the dimensions of contextual performance?

\subsection{Research Objectives}

The research objectives are: (1) to explore the extrinsic motivators affecting communication and media teachers; (2) to explore and analyze the classification of communication and media teachers' contextual performance; and (3) to analyze the correlation between the extrinsic motivators of communication and media teachers and the dimensions of contextual performance. It is hoped that the answers found to the above questions can be of use as a reference for colleges and universities in managing communication and media teachers.

\section{Analysis of Extrinsic Motivators and Relationship Performance of Communication and Media Teachers in Colleges and Universities}

\subsection{Analysis of Extrinsic Motivators of the Communication and Media Teachers in Colleges and Universities}

Cheng, Zhang, and Dong (2010) found that factors encouraging college teachers to engage in teaching mainly include two types, intrinsic motivators and extrinsic motivators. The latter refers to the influence of the external environment or system on media teachers in the process of completing their work. The external environment encourages communication and media teachers to adhere to various rules and regulations, thereby reflecting the binding force of the universities. The extrinsic motivators in this article are mainly from the external environment, such as promotion, salary, and assessment and can be specifically divided into three aspects: (1) salary and benefits, (2) organizational environment, and (3) personal development.

Cheng and Cao (2009) held that salary and benefits are to reduce the emigration of teachers by providing them with direct or indirect compensation such as wages, bonuses, and insurance, and by providing higher economic returns. Chen (2018) believed that the organizational environment is the external environment that affects job performance at a macro level, including organizational culture, working environment and working conditions, and management methods for employees. Colleges and universities have a campus culture, including features such as school motto, school spirit, and differing school management practices which can subtly affect the attitudes and behaviors of teachers and students. Meanwhile, the organizational environment and working conditions are hardware and software closely related to the nature of the job. The organizational environment and working conditions of colleges and universities refer to their investment in scientific research and teaching facilities. The way in which employees are managed depends on the characteristics of the organization (Xu, 2016). In terms of personal development, promotional opportunities have a direct effect on the enthusiasm of employees and at the same time directly affects organizational performance. Therefore, good control of fairness in this process is particularly important to managers (Qian, 2004). Qiang (2011) found that providing teachers with a better development space and working environment to achieve promotion is an important part of personal development and can help to stimulate teachers' greater enthusiasm for work.

\subsection{Analysis of the Contextual Performance Structure of the Communication and Media Teachers in Colleges and Universities}

In China, the overall organizational performance is readily affected by personal subjective emotions and relationships. Therefore, contextual performance plays an important role in the evaluation of organizational performance (Luo \& Zhu, 2006). Some scholars have proposed that teachers have the most contact with students and exert a subtle effect on them. The dedication of college teachers to work, their responsibility for education and teaching, their help for others and other behaviors are more important (Hu, 2009). Van Scotter and Motowidlo (1994) divided task performance and contextual performance, holding that contextual performance should be divided into two dimensions of interpersonal promotion and job dedication. This research was highly recognized by the academic community and became viewed as a major contribution to this field. In this research, contextual performance was primarily divided into surrounding relationships and organizational dedication. Among them, the surrounding relationship is reflected in teachers' relationships with surrounding colleagues, leaders, students, and so forth. Organizational dedication, meanwhile, refers to the teachers' active help to colleagues or students while completing their teaching tasks, and their willingness to assume tasks outside ones' workloads and energetically participate in various meetings or events. 


\subsection{Research Hypothesis}

\subsubsection{Relationship Between Salary and Benefits and the Environment}

A good relationship with the environment is a manifestation of the promotion of interpersonal relationships. Specifically, it refers to voluntarily helping others in an organizational environment, building good interpersonal relationships, and working toward achieving organizational goals ( $\mathrm{Hu}$ et al., 2009). Chen (2009) surveyed teachers to study the relationship between teachers' mental status and job performance in salary satisfaction and found that there was a positive correlation between the two. Based on the above discussion, this current paper proposes the first hypothesis: that salary and benefits are positively related to environment.

H1 Salary and benefits among extrinsic motivators have a positive effect on the relationship with the environment in terms of the contextual performance of communication and media teachers in colleges and universities, and the two are positively correlated.

\subsubsection{Relationship Between Organizational Environment and Surrounding Relationship}

Zhou et al. (2009) found that the quality of individual interpersonal relationships between teachers can affect teachers' job performance. Demographic variables, organizational environment, interpersonal relationships, and job performance are greatly influenced by gender. Thus, it can be seen that organizational environmental factors have a significant effect on contextual performance. Therefore, this current paper proposes the second hypothesis: that the organizational environment is positively related to the surrounding relationship.

H2 Organizational environment among extrinsic motivators has a positive effect on the surrounding relationship in terms of the contextual performance of communication and media teachers in colleges and universities, and the two are positively correlated.

\subsubsection{Relationship Between Personal Development and Surrounding Relationship}

The intention of performance appraisal is to select more responsible managers. Cao (2009) found that joining with colleagues and students through job promotion, title promotion, and participation in training, and appraisal through peer review and student evaluation of teaching can promote teachers' enthusiasm for work and improve their job performance. Therefore, this study proposes the third hypothesis: that personal development is positively related to surrounding relationship.

H3 Personal development among extrinsic motivators has a positive effect on the surrounding relationship in terms of the contextual performance of communication and media teachers in colleges and universities, and the two are positively correlated.

\subsubsection{Relationship Between Salary and Benefits and Organizational Dedication}

Du and Zheng (2011) found that fair salary and benefits have a significant effect on encouraging teachers' work enthusiasm and improving job performance. Li (2011) studied the relationship between salary equity and teacher performance and found that salary equity has a positive impact on teacher performance, and they are positively correlated. Based on the above studies, this paper presents the fourth hypothesis: that salary and benefits are positively related to organizational dedication.

H4 Salary and benefits among extrinsic motivators have a positive effect on organizational dedication in terms of the contextual performance of communication and media teachers in colleges and universities, and the two are positively correlated.

\subsubsection{Relationship Between Organizational Environment and Organizational Dedication}

Zhou (2010) found that the working atmosphere of an organization is related to the performance of teachers. Teachers' job performance is related to the organization's environment and organizational commitment. Organizational commitment and organizational environment affect interpersonal relationships and task performance. The impact of organizational dedication mainly derives from emotional commitment (Xu \& Lu, 2008). Based on these findings, this study presents the fifth hypothesis: that organizational environment and organizational dedication are positively related.

H5 Organizational environment among extrinsic motivators has a positive effect on organizational dedication in terms of the contextual performance of communication and media teachers in colleges and universities, and the two are positively correlated.

\subsubsection{Relationship Between Personal Development and Organizational Dedication}

Enabling each teacher to formulate a clear career development plan and providing them with equal development opportunities can help to enhance their enthusiasm and inherent potential, stimulate their organizational dedication, and maximize the teachers' job performance ( $\mathrm{Wu}$ et al., 2006). Therefore, this study raises the sixth hypothesis: that 
personal development is positively related to organizational dedication.

H6 Personal development among extrinsic motivators has a positive effect on organizational dedication in terms of the contextual performance of communication and media teachers in colleges and universities, and the two are positively correlated.

In conclusion, the research hypothesis is shown in Figure 1.

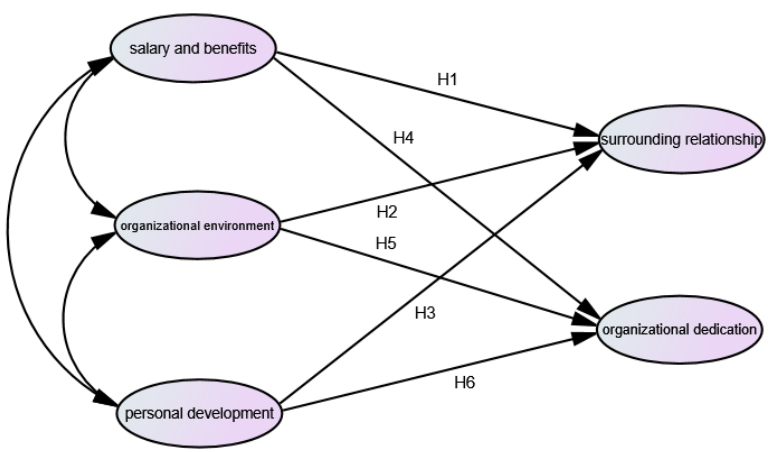

Figure 1. Research hypothesis path diagram

\subsection{Questionnaire Design and Data Collection}

The research technique employed in this research was a questionnaire that was formulated based on a review of the literature and interviews with teachers, students and leaders, which was then checked and refined by a team of experts leading to the adoption of an initial scale of extrinsic motivators and contextual performance. The resulting scale is shown in Table 1. 
Table 1. Items and sources of extrinsic motivators and contextual performance Questionnaire

\begin{tabular}{|c|c|c|c|c|}
\hline $\begin{array}{l}\text { Classificatio } \\
\text { n of } \\
\text { Motivators }\end{array}$ & Dimension & $\begin{array}{l}\text { Order } \\
\text { Number }\end{array}$ & Item & Source \\
\hline \multirow{17}{*}{$\begin{array}{l}\text { extrinsic } \\
\text { motivators }\end{array}$} & \multirow{7}{*}{$\begin{array}{l}\text { salary and } \\
\text { benefits }\end{array}$} & XCFL1 & $\begin{array}{l}\text { My work positivity will be affected by } \\
\text { fluctuations in income }\end{array}$ & \multirow{12}{*}{$\begin{array}{l}\text { Yu, 2014; } \\
\text { Zhang, 2014; } \\
\text { Yu, } 2016\end{array}$} \\
\hline & & XCFL2 & $\begin{array}{l}\text { My enthusiasm for work will be affected by } \\
\text { the gap between my income and the income } \\
\text { of others }\end{array}$ & \\
\hline & & XCFL3 & Salary will affect my work positivity & \\
\hline & & XCFL4 & I will work hard for more income & \\
\hline & & XCFL5 & $\begin{array}{l}\text { Good benefits will affect my enthusiasm for } \\
\text { work }\end{array}$ & \\
\hline & & ZZHJ1 & $\begin{array}{l}\text { I can accept the rules and regulations of the } \\
\text { university }\end{array}$ & \\
\hline & & ZZHJ2 & I have the opportunity to participate in the & \\
\hline & \multirow{6}{*}{$\begin{array}{l}\text { organizational } \\
\text { environment }\end{array}$} & & $\begin{array}{l}\text { decision-making and management of the } \\
\text { university }\end{array}$ & \\
\hline & & ZZHJ3 & $\begin{array}{l}\text { I am currently satisfied with the teaching } \\
\text { facilities and conditions of the university }\end{array}$ & \\
\hline & & ZZHJ4 & $\begin{array}{l}\text { The management layer of the university can } \\
\text { listen to the voice from teachers }\end{array}$ & \\
\hline & & ZZHJ5 & $\begin{array}{l}\text { I quite agree with the theories on school } \\
\text { management }\end{array}$ & \\
\hline & & ZZHJ6 & $\begin{array}{l}\text { The university has created good conditions } \\
\text { for me to take a refresher course and engage } \\
\text { in advanced study }\end{array}$ & \\
\hline & & GRFZ1 & $\begin{array}{l}\text { I am satisfied with the current promotion } \\
\text { system }\end{array}$ & Cheng et al., 2010 \\
\hline & \multirow{4}{*}{$\begin{array}{l}\text { personal } \\
\text { development }\end{array}$} & GRFZ2 & $\begin{array}{l}\text { I attach great importance to the promotion of } \\
\text { positions and titles }\end{array}$ & \\
\hline & & GRFZ3 & $\begin{array}{l}\text { Promotion, training, etc. can stimulate my } \\
\text { work positivity }\end{array}$ & \\
\hline & & GRFZ4 & $\begin{array}{l}\text { There are opportunities for promotion } \\
\text { through hard work }\end{array}$ & \\
\hline & & GRFZ5 & $\begin{array}{l}\text { Promotion is the embodiment of personal } \\
\text { development }\end{array}$ & \\
\hline \multirow{12}{*}{$\begin{array}{l}\text { contextual } \\
\text { relationship }\end{array}$} & \multirow{7}{*}{$\begin{array}{l}\text { surrounding } \\
\text { relationship }\end{array}$} & ZBGX1 & People around me are friendly and trusting & \multirow{7}{*}{$\begin{array}{l}\text { Zou, 2011; } \\
\text { Guo, 2012; } \\
\text { Shi, 2011 }\end{array}$} \\
\hline & & & & \\
\hline & & ZBGX2 & $\begin{array}{l}\text { I often communicate with colleagues and } \\
\text { learn from each other }\end{array}$ & \\
\hline & & ZBGX3 & $\begin{array}{l}\text { I often help colleagues deal with unpleasant } \\
\text { relationships }\end{array}$ & \\
\hline & & ZBGX4 & $\begin{array}{l}\text { I get the respect and understanding of those } \\
\text { around me }\end{array}$ & \\
\hline & & ZBGX5 & The teamwork atmosphere is harmonious & \\
\hline & & ZBGX6 & I am good at dealing with relationships & \\
\hline & \multirow[t]{5}{*}{$\begin{array}{l}\text { organizational } \\
\text { dedication }\end{array}$} & ZZFX1 & $\begin{array}{l}\text { I will help colleagues complete the job when } \\
\text { necessary }\end{array}$ & \multirow[t]{5}{*}{$\begin{array}{l}\text { Zhang, 2014; } \\
\text { Wang, 2012 }\end{array}$} \\
\hline & & ZZFX2 & $\begin{array}{l}\text { I am very concerned about the future } \\
\text { development of the university }\end{array}$ & \\
\hline & & ZZFX3 & $\begin{array}{l}\text { I have made efforts into school affairs besides } \\
\text { my own duties and responsibilities }\end{array}$ & \\
\hline & & ZZFX4 & $\begin{array}{l}\text { I will work overtime to complete other school } \\
\text { affairs when I finish my own work }\end{array}$ & \\
\hline & & ZZFX5 & $\begin{array}{l}\text { I am willing to take on other work besides my } \\
\text { own job }\end{array}$ & \\
\hline
\end{tabular}

The objects of this study were communication and media teachers mainly from education and research colleges and universities. In total, 245 questionnaires were distributed through field distribution, network distribution, and onsite academic conferences. There were 230 copies returned, of which 206 were valid questionnaires, with a recovery rate of $84.1 \%$. 
Table 2. Distribution list of performance motivator sample of communication and media teachers in colleges and universities

\begin{tabular}{|c|c|c|c|c|c|c|c|}
\hline $\begin{array}{l}\text { Demographic } \\
\text { Variable }\end{array}$ & Classification & Number & Percentage & $\begin{array}{l}\text { Demographic } \\
\text { Variable }\end{array}$ & Classification & Number & Percentage \\
\hline \multirow[t]{3}{*}{ gender } & male & 95 & 46.1 & \multirow[t]{3}{*}{$\begin{array}{l}\text { educational } \\
\text { background }\end{array}$} & $\begin{array}{l}\text { bachelor degree } \\
\text { and below }\end{array}$ & 27 & 13.1 \\
\hline & female & 111 & 53.9 & & master degree & 131 & 63.6 \\
\hline & $\begin{array}{l}\text { under the age } \\
\text { of } 30\end{array}$ & 26 & 12.6 & & doctor degree & 41 & 19.9 \\
\hline \multirow[t]{6}{*}{ age } & from 31 to 35 & 37 & 18 & \multirow{4}{*}{$\begin{array}{l}\text { classification of } \\
\text { colleges }\end{array}$} & post-doctor & 7 & 3.4 \\
\hline & from 36 to 40 & 56 & 27.2 & & $\begin{array}{l}\text { ordinary colleges } \\
\text { and universities }\end{array}$ & 179 & 87 \\
\hline & from 41 to 45 & 35 & 17.0 & & Universities of & 27 & 13 \\
\hline & & & & & $\begin{array}{l}\text { "211 Project" } \\
\text { and above }\end{array}$ & & \\
\hline & from 46 to 50 & 23 & 11.2 & holding & yes & 66 & 32 \\
\hline & $\begin{array}{l}\text { above the age } \\
\text { of } 50\end{array}$ & 29 & 14.0 & office post & no & 140 & 68 \\
\hline \multirow[t]{3}{*}{ marital status } & unmarried & 31 & 15 & \multirow[t]{6}{*}{ teaching years } & 1 year or less & 7 & 3.4 \\
\hline & married & 175 & 85 & & 2-10 years & 71 & 34.5 \\
\hline & assistant & 18 & 8.7 & & $11-20$ years & 69 & 33.5 \\
\hline \multirow[t]{3}{*}{ academic title } & lecturer & 90 & 43.7 & & $21-30$ years & 34 & 16.5 \\
\hline & associate & 81 & 39.3 & & 30 years or more & 25 & 12.1 \\
\hline & professor & 17 & 8.3 & & & & \\
\hline
\end{tabular}

Through the analysis of the basic data of communication and media teachers (shown in Table 2), it was found that the data is reasonable and is consistent with the current overall distribution of communication and media teachers in Chinese colleges and universities. Through the analysis of various items of extrinsic motivators, it can be seen that the data reflect the current state of communication and media teachers in Chinese colleges and universities, which can be used as a benchmark for later research.

\section{Research Methods}

\subsection{Independent Sample t-test for Extrinsic Motivators and Contextual Performance of Communication and Media Teachers in Colleges and Universities}

SPSS 25.0 was used to test the various items in terms of the dimensions of the extrinsic motivators in the questionnaire, and the performance measurement values in the questionnaire were summed up. After sorting them in order from low value to high value, the highest $27 \%$ and the lowest $27 \%$ of the 206 questionnaires were calculated and respectively named "low score group" and "high score group". The independent sample t-test was performed on the two groups to determine whether the average value of each item in the two groups was significantly different, and the null hypothesis was that there was a significant difference. Considering the validity of the questionnaire, the items without significant differences should be deleted providing there was not a significant difference. Through testing, there are significant differences in each item of the extrinsic motivators and contextual performance, so there was no need to delete any item.

\subsection{Exploratory Factor Analysis of Extrinsic Motivators and Contextual Performance of Communication and Media Teachers in Colleges and Universities}

Further analysis revealed that the Cronbach's alpha coefficient of each item in the extrinsic motivator questionnaire was 0.795 and that of contextual performance questionnaire was 0.894 , which means that the questionnaire has good reliability in general. The reliability of each sub-item questionnaire was measured, and the reliability analysis of sub-items under salary and benefits, personal development, and organizational environment of extrinsic motivators was performed to find their respective Cronbach's alpha coefficients of $0.858,0.701$, and 0.777 respectively. The reliability of each sub-questionnaire of contextual performance was then measured, and the reliability of sub-items under the surrounding relationship dimension and organizational dedication dimension was analyzed to find their respective Cronbach's alpha coefficients of 0.888 and 0.849 respectively. The reliability coefficients of all sub-scales reached the standard, indicating that they have higher reliability and the measurement results are more reliable.

Then, the KMO and Bartlett spherical tests were performed on the items of each dimension of the extrinsic motivators, and it was found that the KMO measure index was 0.797 , with the significant probability of the Bartlett spherical test being 0.000 , while the KMO measure index of each dimension of the contextual performance was 0.884 , with the significant probability of the Bartlett spherical test being 0.000 . In summary, the above results show that there are 
significant differences between the items in each dimension of extrinsic motivators and contextual performance, thus, they are suitable for factor analysis.

Exploratory factor analysis was applied to extrinsic motivators. Based on the breakdown table of the total variance, the characteristic roots of the first three principal components are all greater than 1, and the characteristic roots of the fourth and the following are less than 1. Moreover, the cumulative contribution rate of the first three principal components reached $58.097 \%$. The scree plot of extrinsic motivators clearly shows that the scatter distribution of the first three principal components is relatively steep and that of the fourth factor tends to be gentle, which reflects the overall information of the questionnaire. The component matrix ${ }^{a}$ table after factor rotation shows that the factor loading of each item is greater than 0.5 after extracting the three principal component factors. Accordingly, a clearer organizational environment factor, salary incentive factor and personal development factor were formed.

Exploratory factor analysis was applied to contextual relationship. Based on the breakdown table of the total variance, the characteristic roots of the first two principal components are all greater than 1, and the characteristic roots of the third and the followings are less than 1. Moreover, the cumulative contribution rate of the first three principal components reached $64.810 \%$. The scree plot of extrinsic motivators clearly shows that the scatter distribution of the first two principal components is relatively steep and that of the third factor tends to be gentle, which reflects the overall information of the questionnaire. The component matrix a table after factor rotation shows that the factor loading of each item is greater than 0.5 after extracting the two principal component factors. Therefore, a relatively clear surrounding relationship factor and organizational dedication factor were also formed.

Table 3. List of principal components of extrinsic motivation and relational performance

\begin{tabular}{|c|c|c|c|c|c|c|}
\hline \multirow{2}{*}{$\begin{array}{l}\text { Extrinsic } \\
\text { motivators }\end{array}$} & \multicolumn{3}{|c|}{ Ingredients } & \multirow{2}{*}{$\begin{array}{l}\text { Contextual } \\
\text { relationship }\end{array}$} & \multicolumn{2}{|c|}{ Ingredients } \\
\hline & 1 & 2 & 3 & & 1 & 2 \\
\hline $\begin{array}{l}\text { ZZHJ4 } \\
\end{array}$ & .816 & -.101 & .084 & ZBGX4 & .862 & .141 \\
\hline ZZHJ5 & .736 & .010 & .159 & ZBGX2 & .855 & .119 \\
\hline ZZHJ6 & .674 & -.149 & .076 & ZBGX1 & .855 & .169 \\
\hline ZZHJ3 & .653 & .031 & -.204 & ZBGX5 & .792 & .222 \\
\hline ZZHJ2 & .580 & -.059 & .140 & ZBGX6 & .613 & .284 \\
\hline ZZHJ1 & .533 & .141 & .052 & ZBGX3 & .597 & .429 \\
\hline XCFL1 & -.062 & .891 & .140 & ZZFX5 & .092 & .846 \\
\hline XCFL3 & -.068 & .886 & .142 & ZZFX4 & .136 & .829 \\
\hline XCFL2 & -.062 & .860 & .033 & ZZFX3 & .208 & .767 \\
\hline XCFL5 & -.040 & .665 & .440 & ZZFX2 & .275 & .741 \\
\hline XCFL4 & -.032 & .602 & .375 & ZZFX1 & .425 & .567 \\
\hline GRFZ2 & .103 & .064 & .811 & & & \\
\hline GRFZ3 & .122 & .174 & .765 & & & \\
\hline GRFZ1 & .074 & -.145 & .739 & & & \\
\hline GRFZ5 & .288 & .062 & .720 & & & \\
\hline GRFZ4 & .246 & -.067 & .608 & & & \\
\hline
\end{tabular}

\section{Results}

In order to further verify the structure rationality of the three dimensions of extrinsic motivators, SEM was used to conduct an in-depth analysis of the model fitting degree of the extrinsic motivator structure. Specifically, AMOS 22.0 software was applied to construct the model, and the data of each item of extrinsic motivators were imported and operated to build an initial model of the intrinsic motivator model of college teachers. The table comparing the status of each model index's reaching the standard can be seen in Table 4. 
Table 4. Comparison of model fitting degree index

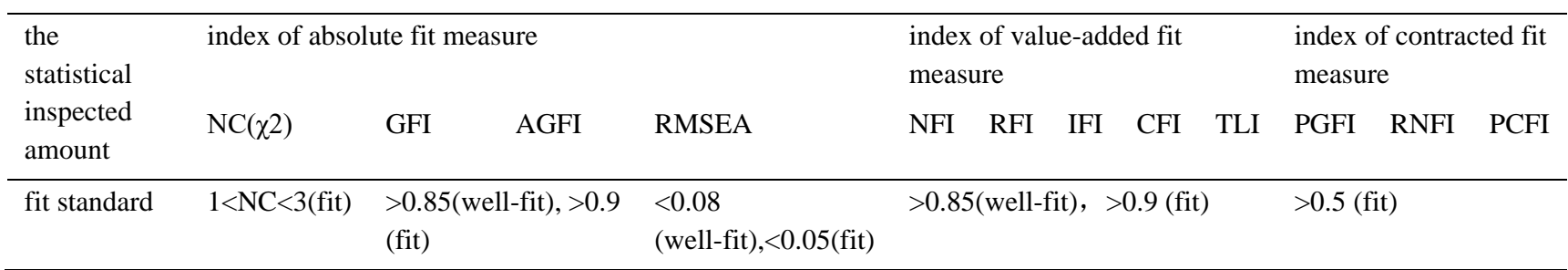

As for the reference items of the discriminant criterion for model fitting degree, Jackson et al. (2009) analyzed the fitting degree items reported in 173 previous papers and found that NC, CFI, AGFI, RMSEA, NFI, IFI, and GFI are common discriminant terms. Therefore, in verifying the model fitting degree, this study mainly aimed at observing whether the values of these items meet the standards.

\subsection{Verification of the Salary and Benefits Measurement Model}

Through measuring the salary and benefit model, it was found that the degree of fit CMIN/df $=6.849$, which did not meet the discriminant index of $\mathrm{CMIN} / \mathrm{df}<3$, indicating that the model fitting index did not reach an acceptable range and degree; the RMSEA (root mean square error of approximation) was 0.169 and failed to meet the criteria of upper limit RMSEA $<0.08$, with GFI (goodness-of-fit index) being 0.943; the AGFI (adjusted goodness-of-fit index) $=0.829$, NFI (normed fitting index) $=0.936$, IFI (incremental fitting index $)=0.945$, CFI (comparative fitting index $)=0.944$, all of those indexes meet the index greater than 0.85 . Based on the above various indicators, there is still room for improvement in the fitting degree of the initial model of salary and benefits. The adjusted index of the model was used to adjust the model, and item 5 of the motivator "salary and benefits" was deleted. After the model was adjusted, the fitting degree index was satisfactory, and shown in Figure 2.
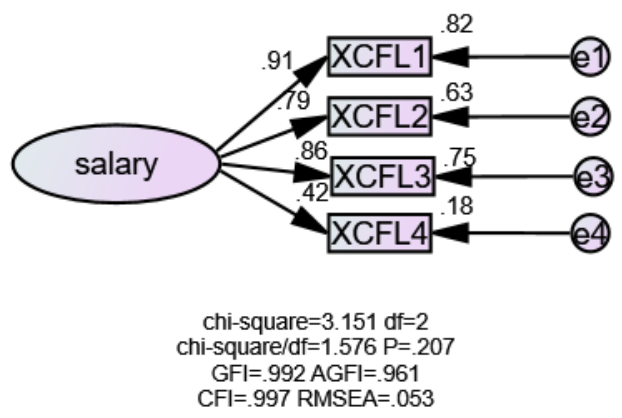

Figure 2. Verification of the salary and benefits measurement model

\subsection{Verification of the Organizational Environment Measurement Model}

Figure 3. Verification of the organizational environment measurement model

Table 5. Organizational environment fit index

\begin{tabular}{llllllll}
\hline model & NC(CMIN/df) & GFI & AGFI & RMSEA & CFI & IFI & NFI \\
\hline $\begin{array}{l}\text { organization } \\
\text { environmental }\end{array}$ & 2.147 & 0.971 & 0.931 & 0.075 & 0.969 & 0.969 & 0.944 \\
\hline
\end{tabular}

By measuring the organization environmental model, it was found that the degree of fitting CMIN / $\mathrm{df}=2.147$, which meets the discriminant index of $\mathrm{CMIN} / \mathrm{df}<3$, suggesting that the model fitting index reaches an acceptable range and degree; the RMSEA (root mean square error of approximation) was 0.075 and failed to meet the criteria of upper limit RMSEA $<0.08$, with GFI (goodness-of-fit index) being 0.971; the AGFI (adjusted goodness-of-fit index) $=0.931$, NFI (normed fitting index $)=0.944$, IFI (incremental fitting index $)=0.969$, CFI (comparative fitting index $)=0.969$, all of those indexes meet the index greater than 0.85 . Based on the above various indicators, the initial model fitting degree of the organizational environment is good. No item deletion is required, as shown in Figure 3. 


\subsection{Verification of the Personal Development Measurement Model}
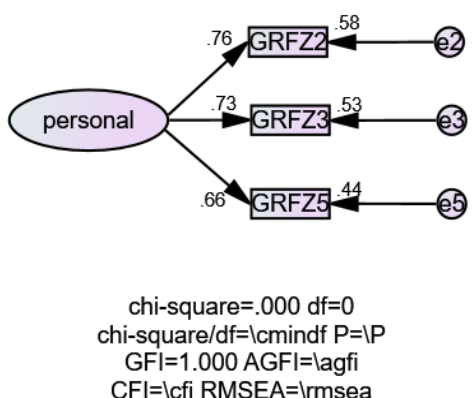

Figure 4. Verification of the personal development measurement model

Table 6. Personal Development fit index

\begin{tabular}{|c|c|c|c|c|c|c|c|}
\hline model & $\mathrm{NC}(\mathrm{CMIN} / \mathrm{df})$ & GFI & AGFI & RMSEA & CFI & IFI & NFI \\
\hline personal development & 13.576 & 0.880 & 0.641 & 0.248 & 0.735 & 0.740 & 0.725 \\
\hline $\begin{array}{l}\text { personal } \\
(\text { modify })\end{array}$ & \multicolumn{7}{|c|}{ meets the basic requirements } \\
\hline
\end{tabular}

By measuring the personal development model, it was found that the degree of fit CMIN/df $=13.57$, which did not meet the discriminant index of $\mathrm{CMIN} / \mathrm{df}<3$, indicating that the model fitting index did not reach an acceptable range and degree; the RMSEA (root mean square error of approximation) was 0.248 and failed to meet the criteria of upper limit RMSEA $<0.08$, with GFI (goodness-of-fit index) being 0.880; the AGFI (adjusted goodness-of-fit index) $=0.641$, NFI (normed fitting index $)=0.725$, IFI (incremental fitting index $)=0.740$, CFI (comparative fitting index) $=0.735$, all of those indexes meet the index greater than 0.85 . Based on the above various indicators, there was still room for improvement in the fitting degree of the initial model of salary and benefits. The adjusted index of the model was used to adjust the model, items 1 and 4 of the motivator "personal development" were deleted, and after adjusting, the model just meets the basic requirements, as shown in Figure 4 and Table 6.

\subsection{Verification of the Surrounding Environment Measurement Model}
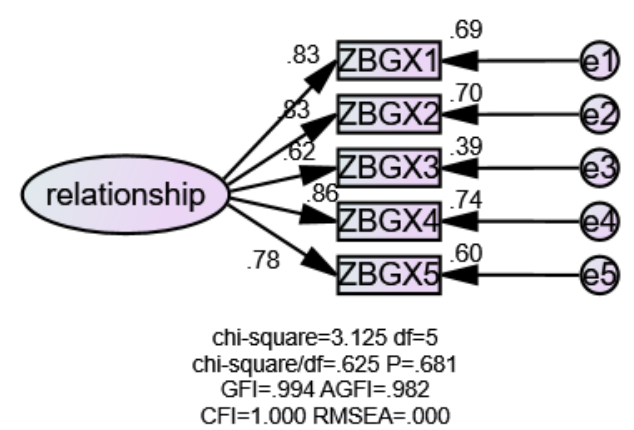

Figure 5. Verification of the surrounding relationship model

Table 7. Surrounding relationship fit index

\begin{tabular}{llllllll}
\hline model & NC(CMIN/df) & GFI & AGFI & RMSEA & CFI & IFI & NFI \\
\hline surrounding relationship & 2.395 & 0.968 & 0.925 & 0.082 & 0.981 & 0.981 & 0.968 \\
surrounding relationship & 0.625 & 0.994 & 0.982 & 0.000 & 1.000 & 1.003 & 0.995 \\
(modify) & & & & & & &
\end{tabular}

The measurement of the surrounding relationship model, it was found that the degree of fit CMIN/df $=2.395$, which did not meet the discriminant index of $\mathrm{CMIN} / \mathrm{df}<3$, indicating that the model fitting index did not reach an acceptable range and degree; the RMSEA (root mean square error of approximation) was 0.082 and failed to meet the criteria of 
upper limit RMSEA $<0.08$, with GFI (goodness-of-fit index) being 0.968; the AGFI (adjusted goodness-of-fit index) = 0.925 , NFI (normed fitting index) $=0.968$, IFI (incremental fitting index $)=0.981$, CFI $($ comparative fitting index $)=$ 0.981 , all of those indexes meet the index greater than 0.85. Based on the above various indicators, there was still room for improvement in the fitting degree of the initial model of salary and benefits. The adjusted index of the model was used to adjust the model, and item 6 of the motivator "surrounding relationship" was deleted. After the model was adjusted, the fitting degree index was satisfactory, as shown in Figure 5 and Table 7.

\subsection{Verification of the Organizational Dedication Measurement Model}

The measurement of the organizational dedication model, it was found that the degree of fit $\mathrm{CMIN} / \mathrm{df}=4.302$, which did not meet the discriminant index of $\mathrm{CMIN} / \mathrm{df}<3$, indicating that the model fitting index did not reach an acceptable range and degree; the RMSEA (root mean square error of approximation) was 0.127 and failed to meet the criteria of upper limit RMSEA $<0.08$, with GFI (goodness-of-fit index) being 0.958; the AGFI (adjusted goodness-of-fit index) = 0.873 , NFI (normed fitting index) $=0.949$, IFI (incremental fitting index $)=0.960$, CFI (comparative fitting index $)=$ 0.960 , all of those indexes meet the index greater than 0.85 . Based on the above various indicators, there was still room for improvement in the fitting degree of the initial model of salary and benefits. The adjusted index of the model was used to adjust the model, and item 2 of the motivator "organizational dedication" was deleted. After the model was adjusted, the fitting degree index was satisfactory, as shown in Figure 6.

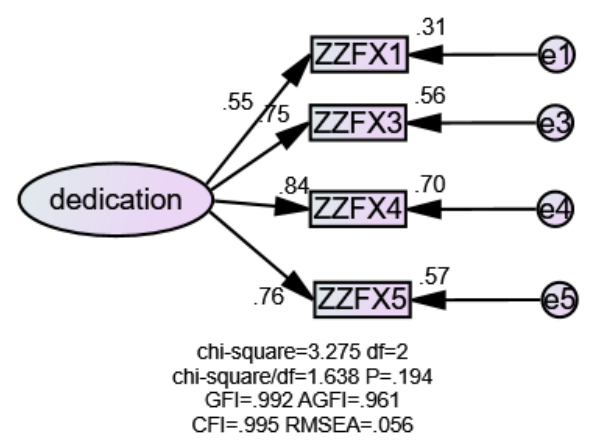

Figure 6. Verification of the organizational dedication measurement

Table 8. Organizational dedication fit index

\begin{tabular}{llllllll}
\hline model & NC(CMIN/df) & GFI & AGFI & RMSEA & CFI & IFI & NFI \\
\hline $\begin{array}{l}\text { organizational dedication } \\
\begin{array}{c}\text { organizational dedication } \\
\text { (modify) }\end{array}\end{array}$ & 4.302 & 0.958 & 0.873 & 0.127 & 0.960 & 0.960 & 0.949 \\
\hline
\end{tabular}

The measurement of the organizational dedication model, it was found that the degree of fit CMIN/df $=4.302$, which did not meet the discriminant index of $\mathrm{CMIN} / \mathrm{df}<3$, indicating that the model fitting index did not reach an acceptable range and degree; the RMSEA (root mean square error of approximation) was 0.127 and failed to meet the criteria of upper limit RMSEA $<0.08$, with GFI (goodness-of-fit index) being 0.958; the AGFI (adjusted goodness-of-fit index) = 0.873 , NFI (normed fitting index) $=0.949$, IFI (incremental fitting index $)=0.960$, CFI $($ comparative fitting index $)=$ 0.960 , all of those indexes meet the index greater than 0.85 . Based on the above various indicators, there was still room for improvement in the fitting degree of the initial model of salary and benefits. The adjusted index of the model was used to adjust the model, and item 2 of the motivator "organizational dedication" was deleted. After the model was adjusted, the fitting degree index was satisfactory, as shown in Figure 6 and Table 8. 


\subsection{Analysis of Composite Reliability and Differential Validity}

Table 9. List of composite reliability and differential validity

\begin{tabular}{|c|c|c|c|c|c|c|c|c|c|}
\hline \multirow{2}{*}{ dimension } & \multirow{2}{*}{ item } & \multicolumn{4}{|c|}{ significant estimation of the parameter } & \multirow{2}{*}{$\begin{array}{c}\text { factor loading } \\
\text { standardized } \\
\text { estimates }\end{array}$} & \multirow{2}{*}{$\begin{array}{c}\text { question } \\
\text { reliability } \\
\text { SMC }\end{array}$} & \multirow{2}{*}{$\begin{array}{c}\text { composite } \\
\text { reliability } \\
\mathrm{CR}\end{array}$} & \multirow{2}{*}{$\begin{array}{c}\text { convergence } \\
\text { validity } \\
\text { AVE }\end{array}$} \\
\hline & & $\begin{array}{c}\text { unstandardized } \\
\text { estimates }\end{array}$ & S.E. & $\mathrm{t}$-value & $\mathrm{P}$ & & & & \\
\hline \multirow[t]{4}{*}{$\begin{array}{l}\text { organizational } \\
\text { dedication }\end{array}$} & ZZFX3 & 1.000 & & & & .746 & .557 & .819 & .536 \\
\hline & ZZFX4 & 1.024 & .098 & 10.423 & $* * *$ & .839 & .704 & & \\
\hline & ZZFX5 & .947 & .096 & 9.908 & $* * *$ & .758 & .575 & & \\
\hline & ZZFX1 & .570 & .078 & 7.301 & $* * *$ & .553 & .306 & & \\
\hline \multirow{5}{*}{$\begin{array}{l}\text { surrounding } \\
\text { relationship }\end{array}$} & ZBGX1 & 1.000 & & & & .832 & .692 & .891 & .623 \\
\hline & ZBGX2 & 1.030 & .074 & 13.922 & $* * *$ & .835 & .697 & & \\
\hline & ZBGX3 & .891 & .094 & 9.433 & $* * *$ & .622 & .387 & & \\
\hline & ZBGX4 & 1.008 & .070 & 14.475 & $* * *$ & .859 & .738 & & \\
\hline & ZBGX5 & 1.001 & .080 & 12.582 & $* * *$ & .776 & .602 & & \\
\hline \multirow[t]{3}{*}{$\begin{array}{l}\text { personal } \\
\text { development }\end{array}$} & GRFZ2 & 1.000 & & & & .762 & .581 & .761 & .516 \\
\hline & GRFZ3 & .931 & .125 & 7.465 & $* * *$ & .726 & .527 & & \\
\hline & GRFZ5 & .991 & .135 & 7.362 & $* * *$ & .664 & .441 & & \\
\hline \multirow[t]{4}{*}{$\begin{array}{l}\text { salary and } \\
\text { benefits }\end{array}$} & XCFL1 & 1.000 & & & & .905 & .819 & .846 & .594 \\
\hline & XCFL2 & .861 & .062 & 13.955 & $* * *$ & .795 & .632 & & \\
\hline & XCFL3 & .937 & .060 & 15.553 & $* * *$ & .864 & .746 & & \\
\hline & XCFL4 & .341 & .056 & 6.121 & $* * *$ & .422 & .178 & & \\
\hline \multirow[t]{6}{*}{$\begin{array}{l}\text { Organizationa } \\
\text { Environment }\end{array}$} & ${ }^{1} \mathrm{ZZHJ} 1$ & 1.000 & & & & .377 & .142 & .784 & .396 \\
\hline & ZZHJ2 & 1.602 & .374 & 4.287 & $* * *$ & .471 & .222 & & \\
\hline & ZZHJ3 & 1.461 & .319 & 4.579 & $* * *$ & .549 & .301 & & \\
\hline & ZZHJ4 & 2.759 & .534 & 5.169 & $* * *$ & .886 & .785 & & \\
\hline & ZZHJ5 & 2.030 & .400 & 5.071 & $* * *$ & .761 & .579 & & \\
\hline & ZZHJ6 & 1.764 & .376 & 4.698 & $* * *$ & .588 & .346 & & \\
\hline
\end{tabular}

Based on the analysis of the average variance variation extraction amount and reliability combination of the five dimensions "salary and benefits, organizational environment, personal development, surrounding relationships, and organizational dedication", the composite reliability of the five dimensions reached above 0.75 , and the AVE values of the five dimensions all met the standards, which shows that the items of the extrinsic motivator questionnaire and those of the contextual performance questionnaire have good convergence validity.

Table 10. List of convergent validity

\begin{tabular}{|c|c|c|c|c|c|c|}
\hline & AVE & $\begin{array}{l}\text { surrounding } \\
\text { relationship }\end{array}$ & $\begin{array}{r}\text { organizational } \\
\text { dedication }\end{array}$ & $\begin{array}{r}\text { Organizational } \\
\text { Environment }\end{array}$ & $\begin{array}{r}\text { salary and } \\
\text { benefits }\end{array}$ & $\begin{array}{r}\text { personal } \\
\text { development }\end{array}$ \\
\hline $\begin{array}{l}\text { surrounding } \\
\text { relationship }\end{array}$ & .623 & .789 & & & & \\
\hline $\begin{array}{r}\text { organizational } \\
\text { dedication }\end{array}$ & .536 & .493 & .732 & & & \\
\hline $\begin{array}{r}\text { Organizational } \\
\text { Environment }\end{array}$ & .396 & .403 & .386 & .629 & & \\
\hline $\begin{array}{r}\text { salary and } \\
\text { benefits }\end{array}$ & .594 & .022 & -.067 & -.127 & .771 & \\
\hline $\begin{array}{r}\text { personal } \\
\text { development }\end{array}$ & .516 & .430 & .524 & .341 & .321 & .718 \\
\hline
\end{tabular}

With discriminant validity used to test the discriminant validity between the dimensions of extrinsic motivators and contextual performance, it was revealed that the square root value of AVE is greater than the correlation coefficient 
between the dimensions, suggesting good discriminant validity between the dimensions of extrinsic motivators and those of contextual performance as shown in Table 9.

\section{Hypothesis Verification}

This section is intended to verify the hypotheses of various dimensions of extrinsic motivators, as well as the surrounding relationship dimension and organizational dedication dimension of contextual performance in order to provide a basis for further proposing more targeted management recommendations or measures.

\subsection{Model Analysis of the Influence of Extrinsic Motivators on Surrounding Relationship}

A standardized path model of the influence of extrinsic motivators on surrounding relationship was constructed to analyze the correlation between salary and benefits, organizational environment, personal development and surrounding relationships, and the influence paths of extrinsic motivators. Through the analysis of the model fitting index by AMOS22 software, it was found that the degree of fit CMIN/df $=1.698$, which meets the discriminant index of $\mathrm{CMIN} / \mathrm{df}<3$, indicating that the model fitting index reaches an acceptable range and degree; RMSEA (root mean square error of approximation) $=0.058$, meeting the criterion of upper limit RMSEA $<0.08$, indicating that the goodness of fit index is fairly good; the GFI (goodness of fit index) $=0.902$; the adjusted goodness of fit index AGFI $=0.870$, which meets the critical value greater than 0.85 ; the standard fit index NFI $=0.944$, incremental fitting index IFI $=0.875$, and CFI (comparative fitting index) $=0.943$; all these satisfy the index greater than 0.85 , further suggesting that the goodness of fit index is fairly good and the model passes the test. More details can be seen in Figure 5.

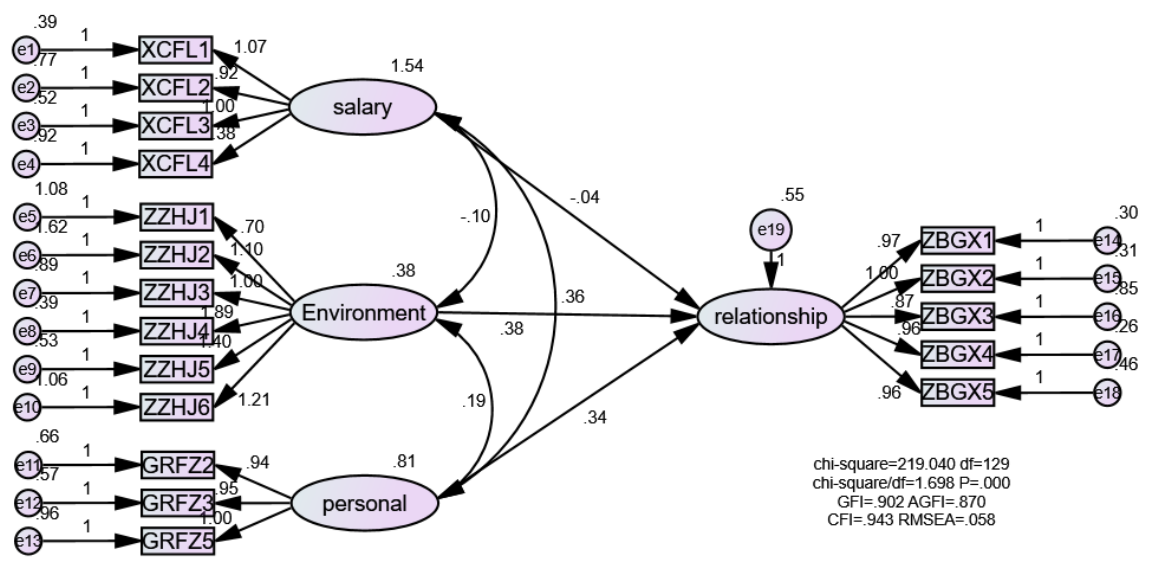

Figure 5. Standardized path initial model of the influence of extrinsic motivators on surrounding relationship

Table 11. Model fitting degree index of the influence of extrinsic motivators on surrounding relationship

\begin{tabular}{llllllll}
\hline model & NC(CMIN/df) & GFI & AGFI & RMSEA & CFI & IFI & NFI \\
\hline test result & 1.698 & 0.902 & 0.870 & 0.058 & 0.943 & 0.875 & 0.944 \\
\hline
\end{tabular}

Based on the analysis of path regression coefficients, the standardized path coefficient of the influence of salary and benefits of communication and media teachers in colleges and universities on the surrounding relationship dimension of the contextual performance is -0.40 , which corresponds to a $\mathrm{P}$ value of 0.471 . This is greater than the significance level of 0.05 , and the original hypothesis $\mathrm{H} 1$ is considered to be invalid; the standardized path coefficient of the influence of organizational environment on the dimension of surrounding relationship in contextual performance is 0.378 , and its corresponding $\mathrm{P}$ value is 0.002 , which is less than the significance level of 0.05 . Therefore, the original hypothesis $\mathrm{H} 2$ is considered to be valid; the standardized path coefficient of the influence of the personal development on surrounding relationship in contextual performance is 0.341 , and its corresponding P value is 0.000 . In this study, the original hypothesis $\mathrm{H} 3$ is considered to be valid. 
Table 12. Path coefficient of the influence of extrinsic motivators on surrounding relationship

\begin{tabular}{lclcccc}
\hline & & & Estimate & S.E. & C.R. & P \\
\hline $\begin{array}{l}\text { surrounding } \\
\text { relationship }\end{array}$ & $<---$ & salary and benefits & -.040 & .055 & -.721 & .471 \\
$\begin{array}{l}\text { surrounding } \\
\text { relationship }\end{array}$ & $<--$ & $\begin{array}{l}\text { Organizational } \\
\text { Environment }\end{array}$ & .378 & .124 & 3.053 & .002 \\
$\begin{array}{l}\text { surrounding } \\
\text { relationship }\end{array}$ & $<--$ & $\begin{array}{l}\text { personal } \\
\text { development }\end{array}$ & .341 & .094 & 3.617 & $* * *$ \\
\hline
\end{tabular}

Through analyzing the influence paths of the various extrinsic motivators of the communication and media teachers in colleges and universities on the surrounding relationship, and the invalid hypothetical path, namely, the influence path of the salary and benefits on the peripheral relations in the model, is deleted, and an optimized model of the standardized path of the influence of extrinsic motivators on surrounding relationship in contextual performance is established to fit the data again to find the optimal model. The model fitting parameter table is shown below, and the final model is shown in Figure 6.

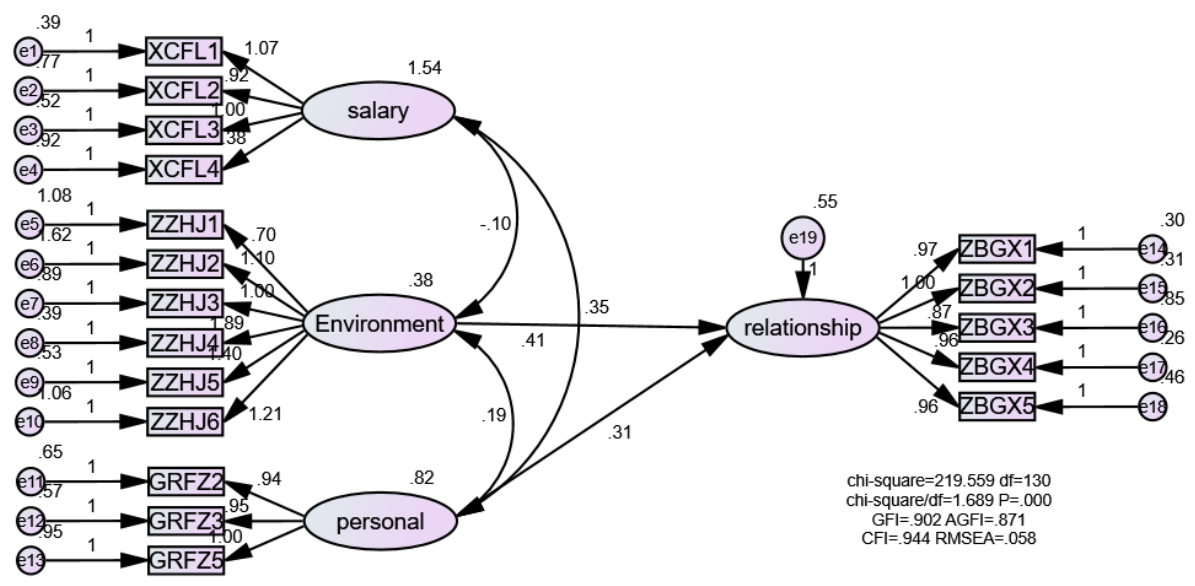

Figure 6. Final model of the standardized path of the influence of extrinsic motivators on surrounding relationship performance

Table 13. Model fitting degree index of the influence of extrinsic motivators on surrounding relationship

\begin{tabular}{llllllll}
\hline model & NC(CMIN/df) & GFI & AGFI & RMSEA & CFI & IFI & NFI \\
\hline test result & 1.689 & 0.902 & 0.871 & 0.058 & 0.944 & 0.945 & 0.874 \\
\hline
\end{tabular}

Through the analysis of the final model path, the organizational environment and personal development have a significant positive effect on the surrounding relationship, and the effect of salary and benefits on the surrounding relationship is not significant. The conclusions are drawn as follows:

H1 Salary and benefits have a positive effect on the surrounding relationship of the contextual performance dimensions, and the two are positively correlated; invalid

H2 Organizational environment has a positive effect on the surrounding relationship of the contextual performance dimensions, and the two are positively correlated; valid

H3 Personal development has a positive effect on the surrounding relationship of the contextual performance dimensions, and the two are positively correlated; valid 


\subsection{Model Analysis of the Influence of Extrinsic Motivators on Organizational Dedication}

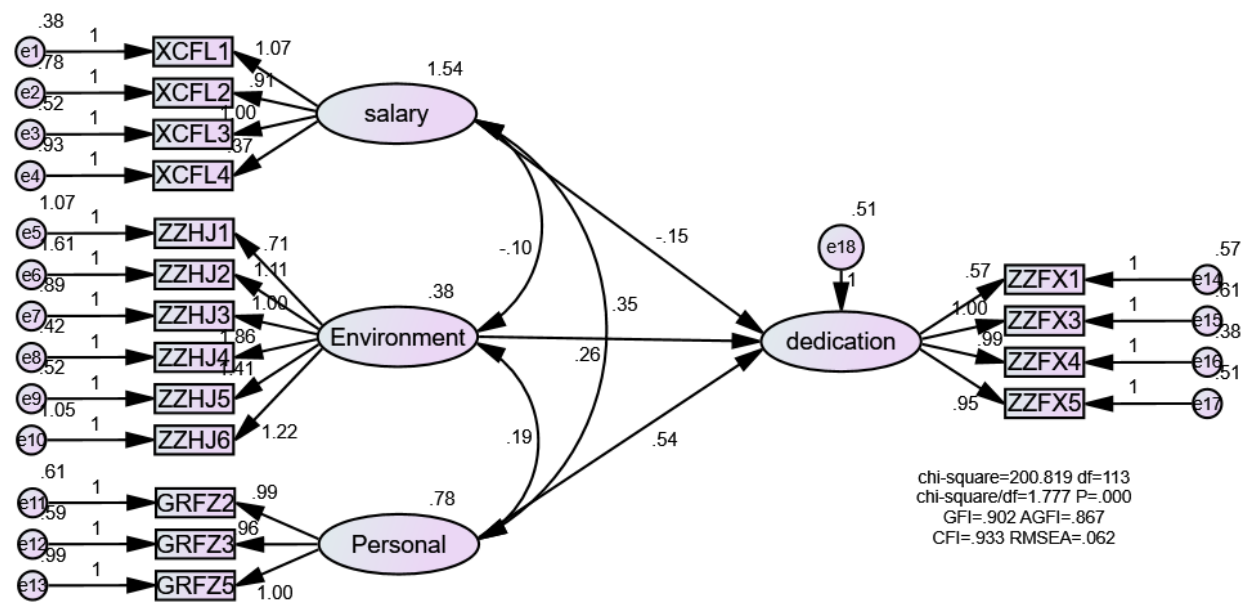

Figure 7. Final model of the standardized path of the influence of extrinsic motivators on organizational dedication performance

Table 14. Model fitting degree index of the influence of extrinsic motivators on organizational dedication

\begin{tabular}{llllllll}
\hline model & NC(CMIN/df) & GFI & AGFI & RMSEA & CFI & IFI & NFI \\
\hline $\begin{array}{l}\text { fitting measurement test } \\
\text { of extrinsic motivators }\end{array}$ & 1.777 & 0.902 & 0.867 & 0.062 & 0.933 & 0.935 & 0.862 \\
$\begin{array}{l}\text { and organizational } \\
\text { dedication model }\end{array}$ & & & & & & & \\
\hline
\end{tabular}

According to Figure 7, a standardized path model of the influence of extrinsic motivators on organizational dedication was established to analyze the correlation between salary and benefits, organizational environment, personal development, and organizational dedication, and the impact path of extrinsic motivators. Through the analysis of the model fitting index by AMOS22.0 software, it was found that the degree of fit CMIN/df $=1.777$, which meets the discriminant index of $\mathrm{CMIN} / \mathrm{df}<3$, indicating that the model fitting index reaches an acceptable range and degree; RMSEA (root mean square error of approximation) $=0.062$, meeting the criterion of upper limit RMSEA $<0.08$, indicating that the goodness of fit index is fairly good; the GFI (goodness of fit index) $=0.902$; the adjusted goodness of fit index AGFI $=0.867$, which meets the critical value greater than 0.85 ; the standard fit index NFI $=0.862$, incremental fitting index IFI $=0.935$, and CFI (comparative fitting index) $=0.933$; all these satisfy the index greater than 0.85 , further suggesting that the goodness of fit index is fairly good and the model passes the test. Based on the analysis of path regression coefficients, the standardized path coefficient of the influence of salary and benefits of communication and media teachers in colleges and universities on the organizational dedication dimension of the contextual performance is -0.155 , which corresponds to a $\mathrm{P}$ value of 0.009 . This is greater than the significance level of 0.05 , and the original hypothesis $\mathrm{H} 4$ is considered to be invalid; the standardized path coefficient of the influence of organizational environment on the dimension of organizational dedication in contextual performance is 0.260 , and its corresponding $\mathrm{P}$ value is 0.039 , which is less than the significance level of 0.05 . Therefore, the original hypothesis $\mathrm{H} 5$ is considered to be valid; the standardized path coefficient of the influence of the personal development on organizational dedication in contextual performance is 0.536 , and its corresponding P value is 0.000 . In this study, the original hypothesis H6 is considered to be valid. Details are shown in Table 13.

Table 15. Path coefficient of the influence of extrinsic motivators on organizational dedication

\begin{tabular}{|c|c|c|c|c|c|c|c|}
\hline & & & Estimate & S.E. & C.R. & $\mathrm{P}$ & Label \\
\hline $\begin{array}{l}\text { organizational } \\
\text { dedication }\end{array}$ & $<--$ & $\begin{array}{l}\text { salary and } \\
\text { benefits }\end{array}$ & -.155 & .060 & -2.595 & .009 & \\
\hline $\begin{array}{l}\text { organizational } \\
\text { dedication }\end{array}$ & $<--$ & $\begin{array}{l}\text { Organizational } \\
\text { Environment }\end{array}$ & . 260. & .126 & 2.060 & .039 & \\
\hline $\begin{array}{l}\text { organizational } \\
\text { dedication }\end{array}$ & $<---$ & $\begin{array}{l}\text { personal } \\
\text { development }\end{array}$ & .536 & .112 & 4.808 & $* * *$ & \\
\hline
\end{tabular}


Through the analysis of the final model path, salary and benefits, organizational environment, and personal development have a significant positive effect on the surrounding relationship. The conclusions are drawn as follows:

H1 Salary and benefits have a positive effect on organizational dedication of the contextual performance dimensions, and the two are positively correlated; valid

H2 Organizational environment has a positive effect on organizational dedication of the contextual performance dimensions, and the two are positively correlated; valid

H3 Personal development has a positive effect on organizational dedication of the contextual performance dimensions, and the two are positively correlated; valid

\section{Discussion and Proposals}

From the model optimization of extrinsic motivators and surrounding relationship, it can be seen that in the process of formulating motivation mechanisms, it is difficult for universities to optimize the relation between communication and media teachers and surrounding relationship through salary and benefits. This reflects the difficulties of promoting the relationships between teachers and teachers, teachers and students, and teachers and leaders by improving the salary and benefits by establishing the salary and benefits motivation system, which may be related to the character, personality, educational background and other environmental factors of communication and media teachers. When formulating a motivation and assessment system for communication and media teachers, universities should pay attention to improving the surrounding environment and perfecting the relationship based on the environment, which is consistent with the so-called principle that "the environment affects people." At the same time, it is necessary to attach importance to the personal development of teachers and improve the relationship with their surroundings through several means, such as providing teachers with opportunities for promotion and reflecting their value.

According to the verification model of extrinsic motivators and organizational dedication, among motivators aimed at communication and media teachers, salary motivator can increase the teachers' dedication to the organization. The higher the salary is, the more it can stimulate the teachers' dedication. Meanwhile, a good organizational environment motivator is a feasible way to stimulate the organizational dedication of communication and media teachers. Attaching importance to personal development, such as promotion, can stimulate communication and media teachers' enthusiasm for work and sense of responsibility, which may further stimulate their dedication to the organization and efforts on its behalf. When developing motivation policies, colleges and universities should focus on inspiring teachers' sense of dedication and responsibility.

\section{References}

Bell, D. (1989). The cultural contradictions of capitalism. SDX Joint Publishing Company.

Cao, Z. Q. (2009). On the characteristics of the needs of college teachers and their incentive strategies. Education and Vocation, 92(8), 56-57.

Chen, D. (2018). Research on the correlation between incentive factors and performance of the general university teachers in Tianjin Province. Tianjin University of Technology.

Chen, J. Y. (2009). The effect of salary satisfaction on job performance and motivation. Human Resources Development of China, 25(8), 101-104.

Cheng, Q. W., \& Cao, X. (2009). Empirical study of the incentive effects of comprehensive salary of research university teachers. Systems Engineering, 27(11), 96-103.

Cheng, W., Zhang, G. L., \& Dong, L. L. (2010). Empirical study on the motivation model of senior university researchers. Science Technology and Management, 12(2), 133-136.

Du, Z. P., \& Zheng, M. (2011). Shallow re-debate university teachers teaching performance incentives. Journal of Shaanxi University of Science \& Technology, 29(6), 185-188.

$\mathrm{Hu}$, J., Fu, C. S., \& Mo, Y. (2009). Comment on the significance of teacher relationship performance in work assessment. Journal of Higher Education, 23(3), 46-47.

Jackson, D. L., Gillaspy, J. A. Jr., \& Purc-Stephenson, R. (2009). Reporting practices in confirmatory factor analysis: An overview and some recommendations. Psychological Methods, 14(1), 6-23. https://doi.org/10.1037/a0014694

Li, T. (2011). A study on the relationship between pay equity and job performance of University Teachers. Education and Vocation, 94(9), 166-168.

Luo, Z. X., \& Zhu, X. (2006). Relations between task performance and contextual performance and job performance. Chinese Journal of Behavioral Medical Science, 15(5), 451-452. 
Motowidlo, S. J., \& Vanscotter, J. R. (1994). Evidence that task performance should be distinguished from contextual performance. Journal of Applied Psychology, 46(79), 475-480. https://doi.org/10.1037/0021-9010.79.4.475

Qian, Z. B. (2004). Theory, policy and practice of human resource management. Tsinghua University Press.

Qiang, M. L. (2011). Human resources development of China, the design of incentive model for University Teachers' remuneration. Human Resources Development of China, 27(7), 95-98.

Wang, D. S. (2012). Factors influencing research performance of university teachers. Beijing Forestry University.

Wu, X. P., Xu, F. Y., \& Zhou, Y. (2006). An analysis of the factors influencing the performance of University Teachers. Journal of East China Normal University (Educational Sciences), 24(1), 30-37.

Xu, S. K., \& Lu, G. L. (2008). Research on the relationship between organizational commitment and work performance of University Teachers. Journal of Psychological Science, 31(4), 987-98.

$\mathrm{Xu}, \mathrm{W}$. (2016). Human resources management in university. Tsinghua University Press.

Yu, H. J. (2016). Research on the motivation factors and performance of university teachers based on the group characteristics. East China Normal University.

Yu, W. J. (1993). China's incentive theory and model. Central China Normal University Press.

Zhang, J. (2014). Research on connection and management mechanism of universities compensation teacher's organizational commitment and job performance. Hebei University of Technology.

Zheng, Y. (2009). Research on job involvement of teachers whose relationship with the motivation-hygiene factor. Zhejiang Normal University.

Zhou, W. B. (2010). A study on the relationship between organizational commitment, organizational climate and teacher performance in private colleges and Universities. Journal of National Academy of Education Administration, 11(12), 23-27.

Zhou, Z. J., Zhu, X. C., W, Y. L., \& Lv, Y. Q. (2009). Investigation and analysis on the job performance of college teachers and its influencing factors. Research in Higher Education of Engineering, 26(2), 111-115.

Zou, X. H. (2011). The relationship between psychological contract and working state of physical Education teachers in Colleges and Universities. Fujian Normal University.

\section{Copyrights}

Copyright for this article is retained by the author(s), with first publication rights granted to the journal.

This is an open-access article distributed under the terms and conditions of the Creative Commons Attribution license which permits unrestricted use, distribution, and reproduction in any medium, provided the original work is properly cited. 